\title{
1 Quality of life profile of methadone maintenance treatment patients in Ho Chi \\ 2 Minh City, Vietnam
}

4 Authors:

$5 \quad$ Vu Thu Trang ${ }^{\mathrm{a}, *}$, Le Ngoc Tu ${ }^{\mathrm{b}, *}, \mathrm{Vu}$ Thi Tuong Vic ${ }^{\mathrm{c}}$, Khuong Quynh Long ${ }^{\mathrm{a}}$, Le Huynh Thi Cam

$6 \quad$ Hong $^{\mathrm{c}, \mathrm{d}}$, Tieu Thi Thu Van ${ }^{\mathrm{e}}$, Do Van Dung ${ }^{\mathrm{c}, \mathrm{d}}$

7 *These authors contribute equally to this work and act as co-first authors

${ }^{a}$ Hanoi University of Public Health, Vietnam

${ }^{b}$ Department of Disease Control and Prevention, Pasteur Institute of Ho Chi Minh City, Vietnam

${ }^{c}$ Vietnam HIV Addiction Technology Transfer Center - University of Medicine and Pharmacy at

Ho Chi Minh City, Vietnam

${ }^{d}$ University of Medicine and Pharmacy at Ho Chi Minh City, Vietnam

ePrevention HIV/AIDS Center Ho Chi Minh City HIV/AIDS Association, Vietnam

\section{Corresponding author:}

Vu Thi Tuong Vi

Vietnam HIV Addiction Technology Transfer Center - University of Medicine and Pharmacy at Ho Chi Minh City, Vietnam, 217 Hong Bang Street, Ward 11, District 5, Ho Chi Minh City, Vietnam.

Phone: +84 (0) 908577 767; Email: tuongvipac@gmail.com

\section{Declarations}

\section{Ethics approval and consent to participate}

27 All procedures performed in studies involving human participants were in accordance with the ethical standards of The Institution Review Board of Ho Chi Minh City HIV/AIDS Center (IRB02-2018, dated 10/08/2018). All participants provided signed informed consent. 
medRxiv preprint doi: https://doi.org/10.1101/2021.08.06.21261540; this version posted August 7, 2021. The copyright holder for this preprint (which was not certified by peer review) is the author/funder, who has granted medRxiv a license to display the preprint in perpetuity.

It is made available under a CC-BY-NC-ND 4.0 International license .

\section{Consent for publication}

31 Not applicable.

\section{Availability of data and material}

33 Available upon request to the corresponding author

\section{Conflict of interest}

35 No potential conflict of interest was reported by the authors.

\section{$36 \quad$ Funding}

37 This study was supported by the South Vietnam HIV Addiction Technology Transfer Center and Ho Chi Minh City HIV/AIDS Center

\section{Authors' contributions}

40 VTT: Conducted data analysis and result explanation, drafted the manuscript

41 LNT: Collected the data, conducted data analysis and result explanation, drafted the manuscript

42 KQL: Designed the study, conducted data analysis and result explanation, provided editorial input

43 VTTV: Designed the study, provided editorial input

44 LHTCH: Participated in study design, provided editorial input

45 TTTV: Participated in study design, provided editorial input

46 DVD: Participated in study design, provided editorial input

47 All authors read and approved the final manuscript.

48

\section{Acknowledgements}

50 The authors would like to thank all MMT patients who participated in this study, colleagues in the

51 South Vietnam HIV Addiction Technology Transfer Center and Ho Chi Minh City HIV/AIDS

52 Center, District 4 and District 8 MMT clinics for supporting this research. 


\section{Quality of life profile of methadone maintenance treatment patients in Ho Chi}

\section{Minh City, Vietnam}

57 Abstract

Aim: To determine the health-related quality of life (HRQoL) of methadone maintenance treatment patients in Ho Chi Minh City, Vietnam.

Subject and Methods: A cross-sectional study was conducted in 967 patients treating at two methadone clinics in Ho Chi Minh City, in 2018. Patient's health-related quality of life was estimated using the EQ-5D-5L and Visual analogue scale (VAS). Tobit regressions were used to identify factors related to patient's health-related quality of life.

Results: Overall, the mean EQ-5D-5L utility and EQ-VAS indexes were $0.96(\mathrm{SD}=0.12)$ and $75.8(\mathrm{SD}=15.5)$, respectively. Factors related with a higher EQ-5D-5L score included peoples who are single, and have a higher monthly income (more than 4 million VND per month), while patients aged under 30 years old, have full-time employment, and have higher education were associated with a higher EQ-VAS score. HIV was associated with lower scores of both EQ-5D-5L and EQVAS ( $\beta=-0.07$ (95\%CI: -0.13; -0.01), and $\beta=-7.10$ (95\%CI: -9.23; -4.98), respectively).

Conclusion: HRQoL measurement provides valuable information for the policymaker to adopt suitable decisions on opioid dependence treatment. The finding shows that patients with education, job situation, and socioeconomic status are the related elements with higher HRQoL, which suggested that the policymakers and physicians should pay more attention to these aspects while working on treatment plan for drug users.

Key words: HRQoL, methadone maintenance treatment, quality of life, Vietnam 
medRxiv preprint doi: https://doi.org/10.1101/2021.08.06.21261540; this version posted August 7, 2021. The copyright holder for this preprint (which was not certified by peer review) is the author/funder, who has granted medRxiv a license to display the preprint in perpetuity.

It is made available under a CC-BY-NC-ND 4.0 International license .

76

77

78

79

80

81

82

83

84

85

86

87

88

89

90

91

92

93

94

95

96

97

98

\section{Introduction}

Since the first introduction in 1947, Methadone maintenance treatment (MMT) has been proved as an efficacious drug treatment modality for heroin addiction (Herget 2005; O'Donnell and Vogenberg 2011; World Health 2004). In Vietnam, the MMT program was originated in 2008, with approximately 53,000 drug users have received treatment in 336 nationwide MMT clinics up to 31th December 2019 (Nguyen et al. 2017c). Coverage of the MMT program in Vietnam had reached $28 \%$ of the total number of people addicted to opiates, treatment adherence rate after six months was $83 \%$, corresponding to the graded good (by World Health Organization standard is $80 \%$ ). Methadone treatment in Vietnam has been shown to be effective in helping patients reduce and eventually stop using illegal drugs, improve health (reduce HIV infection and diseases transmitted through blood, physical enhancement, physical and mental rehabilitation) (MOH 2020).

Health-related quality of life (HRQoL) is a multidimensional construct related to the physical, mental, emotional, and social functioning of an individual, based on their perceptions. HRQoL is becoming increasingly important in assessing treatment outcomes since most opioid-dependent people often experience negative socioeconomic consequences and social exclusion, let alone suffer from adverse health outcomes and high rates of overdose deaths (Strada et al. 2017). Several studies have found the opioid users or those receiving MMT tend to have impaired HRQoL caused by their comorbid infectious diseases, such as hepatitis B virus (HBV), hepatitis C virus (HCV), and HIV (Astals et al. 2008; Korthuis et al. 2008). For instance, Astals et al. conducted a study to assess the quality of life between the general European population and opioid users, the result found that the former group had significantly lower scores compared to the general population (Astals et al. 2008). Other studies used the patient's HRQoL as outcome indicator to evaluate the 
medRxiv preprint doi: https://doi.org/10.1101/2021.08.06.21261540; this version posted August 7, 2021. The copyright holder for this preprint (which was not certified by peer review) is the author/funder, who has granted medRxiv a license to display the preprint in perpetuity.

It is made available under a CC-BY-NC-ND 4.0 International license .

99

100

101

102

103

104

105

106

107

108

109

110

111

112

113

114

115

116 117 participated in the study.

118

119

120

121 Health 2014). City, Vietnam.

\section{Method}

\section{Setting and participants}

\section{Procedure and measurement}

effectiveness of MMT program (Karow et al. 2011; Lashkaripour et al. 2012; Strada et al. 2017). For example, research conducted in HCMC and Hai Phong showed the number of patients with good HRQoL increased from $16 \%$ to $55 \%$ after 3 months of treatment (Vietnamese Ministry of

Although many studies have explored the HRQoL of opioid users, only a few have examined variations in their scores and determinants factors (Korthuis et al. 2008; Nguyen et al. 2017b; Quyen et al. 2020). A comprehensive understanding of the relationships between HRQoL and MMT is important for developing response strategies to the opioid. This is especially of importance in the context of Vietnam, there are little shreds of evidence that summarize specific linking associated factors to the quality of life for people with opioid dependence. This study was conducted to examine the HRQoL and its determinants among MMT patients in Ho Chi Minh

This cross-sectional study was conducted at two MMT clinics in District 8 and District 4, Ho Chi Minh City (HCMC). The inclusion criteria for the survey included: (1) $\geq 18$ year olds, (2) currently visiting the clinic during the study period and (3) having the ability to answer the questionnaire. There were 1,039 eligible patients in two clinics, among them, 967 people $(93.1 \%)$ agreed and

Patients who met the inclusion criteria were invited to private rooms. Subsequently, they were given the verbal introduction of the study and confirmed their enrollment by signing the consent form. Those who refused to participate continued their usual treatment at the clinic. The 
medRxiv preprint doi: https://doi.org/10.1101/2021.08.06.21261540; this version posted August 7, 2021. The copyright holder for this preprint (which was not certified by peer review) is the author/funder, who has granted medRxiv a license to display the preprint in perpetuity.

It is made available under a CC-BY-NC-ND 4.0 International license .

122 questionnaire was conducted by face-to-face interviews in around 25-30 minutes. Data collectors

123 were well-trained preventive medicine doctors from Addiction Technology Transfer Center,

124 University of Medicine and Pharmacy at Ho Chi Minh City. Clinic staffs were not involved in this

125 process to avoid potential bias.

126

127

128

129

130

131

132

133

134

135

136

137

138

139

140

141

142

143

144

\section{Outcome variables}

The primary outcome of this study was quality of life measured by The EuroQol-five (EQ-5D-5L) and The Visual Analogue Scale (EQ-VAS). The EQ-5D-5L includes five dimensions which describe different aspects of life: mobility, self-care, usual activities, pain/discomfort, and anxiety/depression. In each dimension, a Likert rating scale of five response levels (no problemscode 1 , slight problems-code 2 , moderate problems-code 3 , severe problems- code 4 , unable to/extreme problems-code 5) is used. The numbers for each dimension can be combined to a 5digit code ranging from 11111 (no problems) to 55555 (worst health). The overall EQ-5D-5L score is calculated by using the crosswalk value set in the data of EuroQuoL (EuroQol Research Foundation 2019).

The Visual Analogue Scale (EQ-VAS) is developed to assess the self-rated health of patients. The scale ranges from 0 (the worst health you can imagine) to 100 points (the best health you can imagine) (EuroQol Research Foundation 2019). The Vietnamese version of EQ-5D-5L and EQVAS have been translated, validated and used in many previous studies in Vietnam (Nguyen et al. 2017a; Tran et al. 2018; Tran et al. 2012).

\section{The Alcohol, Smoking and Substance Involvement Screening Test (ASSIST)}

The Alcohol, Smoking and Substance Involvement Screening Test (ASSIST) was included to investigate the risk of concurrent drug use among respondents. The ASSIST was developed by the Word Health Organization (WHO) and designed to be culturally neutral and useable in primary 
medRxiv preprint doi: https://doi.org/10.1101/2021.08.06.21261540; this version posted August 7, 2021. The copyright holder for this preprint (which was not certified by peer review) is the author/funder, who has granted medRxiv a license to display the preprint in perpetuity.

It is made available under a CC-BY-NC-ND 4.0 International license .

145 care setting across a variety of cultures. The tool contains a total of 8 questions collecting

146 information about lifetime use of 9 common substances, use of these substances and associated

147 problems over the last 3 months. Patients being assessed as "medium risk" or "high risk" were

148 defined as hazardous substance users (World Health Organization (WHO) 2010).

149 Clinical data extraction

150 MMT treatment information of participants including duration on MMT, daily methadone dosage,

151 number of doses missed within last 3 months and comorbidities (HIV, tuberculosis, hepatitis B,

152 and hepatitis C) were extracted from the medical records.

153 Urine samples of respondents were collected and tested for methamphetamine (a substance of ATS

154 group) using rapid urine test (ABON, Biopham Co. Ltd). This process was implemented by well-

155 trained laboratory staffs.

156 Data analysis

157 Descriptive statistics were used to summarize the data, with frequencies and percentages for 158 categorical variables and means with standard deviations (SD) or median with inter-quartile ranges 159 (IQR) for quantitative variables. To detect the differences between EQ-5D-5L and EQ-VAS scores 160 among respondents, we used t-tests, ANOVA tests or Wilcoxon Rank Sum tests when appropriate.

161 Tobit regressions were conducted to identify factors associated with EQ-5D-5L and EQ-VAS

162 scores. A significant level of $\mathrm{p}<0.05$ was used for all statistical tests. All analyses were carried 163 out using Stata v16 (Stata Corp, College Station, TX).

164 Ethics

165 All procedures performed in studies involving human participants were in accordance with the 166 ethical standards of the Institution Review Board of Ho Chi Minh City HIV/AIDS Center (IRB167 02-2018, dated 10/08/2018). All participants provided signed informed consent. 
medRxiv preprint doi: https://doi.org/10.1101/2021.08.06.21261540; this version posted August 7, 2021. The copyright holder for this preprint (which was not certified by peer review) is the author/funder, who has granted medRxiv a license to display the preprint in perpetuity.

It is made available under a CC-BY-NC-ND 4.0 International license .

168

169

170

171

172

173

174

175

176

177

178

179

180

181

182

183

184

185

186

187

188

189

190

\section{Results}

A total of 967 participants enrolled into the study. Patients' demographic characteristics are shown in Table 1. Most of participants were male (89.9\%), aged from 30 to 49 (81.8\%), having full-time job $(74.3 \%)$ and being married or living with partners $(46.4 \%)$. Nearly a haft of respondents (47.8\%) finished secondary school and had a monthly income from 4 to 8 million VND (44.8\%).

The majority of patients had ever injected drugs (78.0\%), while only $12.4 \%$ respondents still injected drugs within the past three months. About $60 \%$ of them had the duration on MMT between 1 to 5 years, with prevalent dose for methadone was 60-120 mg/day (41.2\%). Moreover, 44.8\% participants reported missing at least one dose in past 3 months. The proportions of participants with positive $\mathrm{HIV}, \mathrm{HBV}, \mathrm{HCV}$ and tuberculosis were $33.9 \%, 9.7 \%, 41.9 \%$ and $1.0 \%$, respectively.

(Table 1 is about here)

Table 2 shows profiles of EQ-5D-5L domains according to frequencies of each item response. The highest proportion of respondents reporting any problems was in pain/discomfort domain (14.2\%), followed by anxiety/ depression (14.1\%), usual activities (7.2\%) and mobility (6.7\%), the lowest percentage was in Self-care $(2.8 \%)$.

\section{(Table 2 is about here)}

The mean EQ-5D-5L utility scores and EQ-VAS scores by different characteristics are summerized in table 3. Overall, the mean EQ-5D-5L and EQ-VAS indexes were $0.96(\mathrm{SD}=0.12)$ and $75.8(\mathrm{SD}=15.5)$, respectively. Lower EQ-5D-5L and EQ-VAS scores were found older patients and those having lower education, and having unstable job. Patients who had monthly income under 4 million VND had lower EQ-5D-5L and EQ-VAS indexs compared to other groups $(\mathrm{p}<0.001)$. We also found significant differences on EQ-5D-5L and EQ-VAS scores in term of 
medRxiv preprint doi: https://doi.org/10.1101/2021.08.06.21261540; this version posted August 7, 2021. The copyright holder for this preprint (which was not certified by peer review) is the author/funder, who has granted medRxiv a license to display the preprint in perpetuity.

It is made available under a CC-BY-NC-ND 4.0 International license .

duration on MMT, daily methadone dose, dose missed in the last 3 months. Notably, people being positive with HIV, hepatitis B, C or having ARV treatment also had lower EQ-5D-5L score or EQVAS index than their counterparts.

\section{(Table 3 is about here)}

Table 4 shows the association between EQ-5D-5L and EQ-VAS scores and different kinds of substance use. Patients being hazardous ATS and cannabis users had 5 points and 7 points lower than the others in EQ-VAS index, respectively $(\mathrm{p}<0.001$ for ATS use and $\mathrm{p}=0.043$ for cannabis use).

\section{(Table 4 is about here)}

Table 5 illustrates ten most common EQ-5D-5L health states, which accounted for $91.3 \%$ of participants. Health conditions "11111" (full health), "11112" (slightly problems in anxiety/depression) and "11121" (slightly problems in pain/discomfort) were the most frequent statuses among respondents.

\section{(Table 5 is about here)}

The final multivariate model revealed four factors related to EQ-5D-5L scores. Patients who were married/live with partners and those who were divorced/separated/widowed had lower EQ-5D-5L scores, compared with patients who were single, $(\beta=-0.08 ; 95 \% \mathrm{CI}:-0.14,-0.01$ and $\beta=-0.09$; 95\%CI: $-0.17,-0.01$, respectively) . Similarly, the lower scores were found in patients who had unstable job compared to those having full-time job $(\beta=-0.10 ; 95 \% \mathrm{CI}:-0.19,-0.01$ in part-time job and $\beta=-0.09$; 95\%CI:-0.18,-0.01 in unemployed) or being positive with HIV ( $\beta=-0.07$; 95\%CI: 0.13,-0.01). By contrast, patients had higher EQ-5D-5L score when they got higher monthly income $(\beta=0.12 ; 95 \% \mathrm{CI}: 0.04,0.20$ in $4-8$ million $\mathrm{VND}$ and $\beta=0.12 ; 95 \% \mathrm{CI}: 0.02,0.21$ in $>8$ million VND). 
medRxiv preprint doi: https://doi.org/10.1101/2021.08.06.21261540; this version posted August 7, 2021. The copyright holder for this preprint (which was not certified by peer review) is the author/funder, who has granted medRxiv a license to display the preprint in perpetuity.

It is made available under a CC-BY-NC-ND 4.0 International license .

214 Similar results were found in the final model for EQ-VAS scores. The lower EQ-VAS scores were

215 found in patients having unstable job as compared to those having full-time job $(\beta=-4.24 ; 95 \% \mathrm{CI}$ :

$216-7.38,-1.08$ for part-time job and $\beta=-5.17 ; 95 \% \mathrm{CI}:-7.98,-2.36$ for unemployed), having HIV

217 positive serostatus $(\beta=-7.10 ; 95 \% \mathrm{CI}:-9.23,-4.98)$, aged $\geq 50$ years $(\beta=-12.78$; 95\%CI: $-17.56,-$

218 8.01) and having hazardous ATS use ( $\beta=-5.97 ; 95 \% \mathrm{CI}:-8.60,-3.35)$. Whereas, patients who

219 finished secondary school or above had higher EQ-VAS scores than those who did not. (Table 6)

220

(Table 6 is about here)

\section{Discussion}

222 The mean score of EQ-5D-5L and EQ-VAS in our study were $0.96(\mathrm{SD}=0.12)$ and 75.8

$223(\mathrm{SD}=15.5)$, respectively, which were higher than that of the methadone patients in the North

224 mountain area in Vietnam $0.88(\mathrm{SD}=0.20)$ and long-term treatment with methadone patients in

225 Norway 0.699 (0.25) (Nguyen et al. 2017b). This difference could happen due to the differences

226 in geographical location, social distinctions, economic status, and culture.

227 Our results indicated that MMT patients aged from 30 to 50 years old usually did not experience

228 significant pain/discomfort and anxiety/depression symptoms in their daily life. These symptoms

229 were more frequently reported among patients who were lower than 30 or older than 50 years old.

230 This finding was consistent with the previous study in Vietnam, in which, the prevalence of

231 anxiety/depression was the most common symptom among study participants (Tran et al. 2011).

232 The two problems (pain/discomfort and anxiety/depression) were also the most frequently reported

233 by MMT patients in Poland (Golicki and Niewada 2017). Notably, 77.8\% of participants in our

234 study reported with the health states as 11111 (perfect health state) indicated that the quality of life

235 among MMT patients in Vietnam was relatively high. 
medRxiv preprint doi: https://doi.org/10.1101/2021.08.06.21261540; this version posted August 7, 2021. The copyright holder for this preprint (which was not certified by peer review) is the author/funder, who has granted medRxiv a license to display the preprint in perpetuity.

It is made available under a CC-BY-NC-ND 4.0 International license .

We found that the patient's age, education, marital status, employment status, and socioeconomic status were significantly associated with their HRQoL. Specifically, the HRQoL scores were lower among older patients, which is in line with previous research in Vietnam, Uruguay, England and Germany (Augustovski et al. 2016; Feng et al. 2015; Hinz et al. 2014). Patients with higher education, being employed, and having high socioeconomic had higher HRQoL than the other groups. It could be explained that people with stable income and jobs are easier to access MMT services, and people with higher education are more likely to adopt/adherence the MMT treatment and have the self-awareness to break the addiction (Quyen et al. 2020; Sadeghi et al. 2017).

Consistent with previous studies, our study revealed patients involving in the MMT program more than five years had lower score of EQ-VAS as compared to those being treated in less than 5 years. (Babaie and Razeghi 2013; Quyen et al. 2020). The results also showed patients who missed dose had a higher score than adherence patients. Since the causal relationship has not been confirmed yet, this finding raises the question that MMT treatment effective may lead to miss dose decision in MMT patient.

In the present study, $33.9 \%$ of participants had HIV, and $96.8 \%$ of them were on ARV treatment, among these, we found patients living with HIV had lower HRQoL. According to previous studies, comorbidities contribute to lower HRQoL because they lead to poorer health status (Tran 2012; Tran et al. 2011; Wang et al. 2014). ARVs have the effect of inhibiting the reproduction of HIV but can bring side effects for the users. Therefore, it is as expected that the lower HRQoL scores were found among these patients. However, the most difficult thing that these patients had to face was experiencing social stigma and discrimination (Quyen et al. 2020).

Besides, HIV patients also bear the burden of treatment-related costs and are limited in daily activities (Wang et al. 2014). In Vietnam, health insurance does not cover the costs of daily 
medRxiv preprint doi: https://doi.org/10.1101/2021.08.06.21261540; this version posted August 7, 2021. The copyright holder for this preprint (which was not certified by peer review) is the author/funder, who has granted medRxiv a license to display the preprint in perpetuity.

It is made available under a CC-BY-NC-ND 4.0 International license . events that could affect HRQoL.

consumables that methadone used but pays for routine laboratory tests and costs for treatment of adverse effects and comorbidities in compliance with regulations by Vietnam's Ministry of Health. Accordingly, drug users with insurance when participating in MMT are less worried about paying additional treatment and laboratory test costs. The previous study has shown this policy helps insurance patients sought and received treatment more promptly, sufficiently, and properly than those who had to pay for treatment by themselves (Quyen et al. 2020). In our study, patients being hazardous ATS users had lower EQ-VAS scores than their counterparts. A previous study demonstrated that drug use among MMT patients was still a rising problem that could decrease their health and quality of life (Le et al. 2021). Long-term ATS use negatively leads to intoxication, emotional disorder, anxiety and increases high-risk sexual behaviors such as unprotected sex and sex with multiple partners (Radfar and Rawson 2014; Volkow et al. 2007). Our finding indicates the need for programs on controlling ATS use among MMT patients, including screening, provide urine testing for the patient as a regular test. Besides, other interventions to help patients withdraw from ATS are needed to maintain better outcomes for MMT patients (Shariatirad et al. 2013).

Our study has several limitations. First, as a cross-sectional survey, the results could not be interpreted as causal relationship. Second, as all the participants are recruited in Ho Chi Minh City, the results might not be generalized for MMT patients in other areas. Further studies in Vietnam are needed to thoroughly explore the associated factors with HRQoL among MMT patients, including the different elements between male and female patients, social stigma, or psychology 
medRxiv preprint doi: https://doi.org/10.1101/2021.08.06.21261540; this version posted August 7, 2021. The copyright holder for this preprint (which was not certified by peer review) is the author/funder, who has granted medRxiv a license to display the preprint in perpetuity. It is made available under a CC-BY-NC-ND 4.0 International license.

\section{Conclusion}

282 HRQoL measurement provides valuable information for the policymaker to adopt suitable 283 decisions on opioid dependence treatment. The finding shows that patients with education, job

284 situation, and socioeconomic status are the related elements with higher HRQoL, which suggested 285 that the policymakers and physicians should pay more attention to these aspects while working on 286 treatment plan for drug users.

\section{Conflict of interest}

288 The authors declare that they have no conflict of interest. 
medRxiv preprint doi: https://doi.org/10.1101/2021.08.06.21261540; this version posted August 7, 2021. The copyright holder for this preprint (which was not certified by peer review) is the author/funder, who has granted medRxiv a license to display the preprint in perpetuity.

It is made available under a CC-BY-NC-ND 4.0 International license.

290

291

292

293

294

295

296

297

298

299

300

301

302

303

304

305

306

307

308

309

310

311

312

\section{References}

Astals M, Domingo-Salvany A, Buenaventura CC, Tato J, Vazquez JM, Martín-Santos R, Torrens M (2008) Impact of substance dependence and dual diagnosis on the quality of life of heroin users seeking treatment Subst Use Misuse 43:612-632 doi:10.1080/10826080701204813

Augustovski F et al. (2016) An EQ-5D-5L value set based on Uruguayan population preferences Qual Life Res 25:323-333 doi:10.1007/s11136-015-1086-4

Babaie E, Razeghi N (2013) Comparing the effects of methadone maintenance treatment, therapeutic community, and residential rehabilitation on quality of life and mental health of drug addicts Addict Health 5:16-20

EuroQol Research Foundation (2019) EQ-5D-5L User Guide. Rotterdam, Netherlands

Feng Y, Devlin N, Herdman M (2015) Assessing the health of the general population in England: how do the three- and five-level versions of EQ-5D compare? Health Qual Life Outcomes 13:171 doi:10.1186/s12955-015-0356-8

Golicki D, Niewada M (2017) EQ-5D-5L Polish population norms Arch Med Sci 13:191-200 doi:10.5114/aoms.2015.52126

Herget G (2005) Methadone and buprenorphine added to the WHO list of essential medicines. Canada

Hinz A, Kohlmann T, Stöbel-Richter Y, Zenger M, Brähler E (2014) The quality of life questionnaire EQ-5D-5L: psychometric properties and normative values for the general German population Qual Life Res 23:443-447 doi:10.1007/s11136-013-0498-2

Karow A, Verthein U, Pukrop R, Reimer J, Haasen C, Krausz M, Schäfer I (2011) Quality of life profiles and changes in the course of maintenance treatment among 1,015 patients with 
medRxiv preprint doi: https://doi.org/10.1101/2021.08.06.21261540; this version posted August 7, 2021. The copyright holder for this preprint (which was not certified by peer review) is the author/funder, who has granted medRxiv a license to display the preprint in perpetuity. It is made available under a CC-BY-NC-ND 4.0 International license .

severe opioid dependence Subst Use Misuse

46:705-715 doi:10.3109/10826084.2010.509854

Korthuis T et al. (2008) Health-Related Quality of Life in HIV-Infected Patients: The Role of Substance Use AIDS patient care and STDs 22:859-867 doi:10.1089/apc.2008.0005

Lashkaripour K, Bakhshani NM, Sadjadi SA (2012) Quality of life in patients on methadone maintenance treatment: a three-month assessment J Pak Med Assoc 62:1003-1007

Le NT et al. (2021) Prevalence of Amphetamine-Type Stimulant Use and Related Factors among Methadone Maintenance Patients in Ho Chi Minh City Vietnam: A Cross-Sectional Study Journal of psychoactive drugs:1-9 doi:10.1080/02791072.2020.1871126

MOH (2020) Draft Guide to pilot implementation of multi-day methadone supply for patients receiving opioid addiction treatment. Vietnamese Ministry of Health,

Nguyen LH et al. (2017a) Quality of life and healthcare service utilization among methadone maintenance patients in a mountainous area of Northern Vietnam Health and quality of life outcomes 15:77

Nguyen LH et al. (2017b) Quality of life and healthcare service utilization among methadone maintenance patients in a mountainous area of Northern Vietnam Health Qual Life Outcomes 15:77 doi:10.1186/s12955-017-0633-9

Nguyen LH et al. (2017c) Psychological Distress Among Methadone Maintenance Patients in Vietnamese Mountainous Areas AIDS Behav 21:3228-3237 doi:10.1007/s10461-017$1779-5$

O'Donnell J, Vogenberg FR (2011) Applying legal risk management to the clinical use of methadone P T 36:813-822 
medRxiv preprint doi: https://doi.org/10.1101/2021.08.06.21261540; this version posted August 7, 2021. The copyright holder for this preprint (which was not certified by peer review) is the author/funder, who has granted medRxiv a license to display the preprint in perpetuity.

It is made available under a CC-BY-NC-ND 4.0 International license .

Quyen BTT, Nguyen LT, Phuong VTV, Hoang LT (2020) Quality of life in methadone maintenance treated patients in Long An, a southern province of Vietnam Health Psychol Open 7:2055102920953053-2055102920953053 doi:10.1177/2055102920953053

Radfar SR, Rawson RA (2014) Current research on methamphetamine: epidemiology, medical and psychiatric effects, treatment, and harm reduction efforts Addict Health 6:146-154

Sadeghi N, Davaridolatabadi E, Rahmani A, Ghodousi A, Ziaeirad M (2017) Quality of life of adolescents and young people arrive at an addiction treatment centers upon their admission, and 1, 4 and 8 months after methadone maintenance therapy J Educ Health Promot 6:9595 doi:10.4103/jehp.jehp_297_13

Shariatirad S, Maarefvand M, Ekhtiari H (2013) Methamphetamine use and methadone maintenance treatment: an emerging problem in the drug addiction treatment network in Iran Int J Drug Policy 24:e115-116 doi:10.1016/j.drugpo.2013.05.003

Strada L, Vanderplasschen W, Buchholz A, Schulte B, Muller AE, Verthein U, Reimer J (2017) Measuring quality of life in opioid-dependent people: a systematic review of assessment instruments Qual Life Res 26:3187-3200 doi:10.1007/s11136-017-1674-6

Tran BX (2012) Quality of life outcomes of antiretroviral treatment for HIV/AIDS patients in Vietnam PloS one 7:e41062-e41062 doi:10.1371/journal.pone.0041062

Tran BX, Nguyen LH, Nguyen CT, Latkin CA (2018) Health-related work productivity loss is low for patients in a methadone maintenance program in Vietnam The International journal on drug policy 60:1-7 doi:10.1016/j.drugpo.2018.07.007

Tran BX, Ohinmaa A, Nguyen LT (2012) Quality of life profile and psychometric properties of the EQ-5D-5L in HIV/AIDS patients Health and Quality of Life Outcomes 10:132 doi:10.1186/1477-7525-10-132 
medRxiv preprint doi: https://doi.org/10.1101/2021.08.06.21261540; this version posted August 7, 2021. The copyright holder for this preprint (which was not certified by peer review) is the author/funder, who has granted medRxiv a license to display the preprint in perpetuity. It is made available under a CC-BY-NC-ND 4.0 International license .

358 Tran BX, Ohinmaa A, Nguyen LT, Nguyen TA, Nguyen TH (2011) Determinants of health-related 359 quality of life in adults living with HIV in Vietnam AIDS care 23:1236-1245 doi:10.1080/09540121.2011.555749

361 Vietnamese Ministry of Health FU (2014) Evaluate the effectiveness of methadone treatment for opioid addiction treatment in Hai Phong and Ho Chi Minh City for the period 2009-2011.

363 Volkow ND, Wang GJ, Fowler JS, Telang F, Jayne M, Wong C (2007) Stimulant-induced 364 enhanced sexual desire as a potential contributing factor in HIV transmission The American journal of psychiatry 164:157-160 doi:10.1176/ajp.2007.164.1.157

366 Wang Y et al. (2014) Reduced responses to heroin-cue-induced craving in the dorsal striatum: effects of long-term methadone maintenance treatment Neurosci Lett 581:120-124 doi:10.1016/j.neulet.2014.08.026 medicines.

371 World Health Organization (WHO) (2010) The Alcohol, Smoking and Substance Involvement 
medRxiv preprint doi: https://doi.org/10.1101/2021.08.06.21261540; this version posted August 7, 2021. The copyright holder for this preprint (which was not certified by peer review) is the author/funder, who has granted medRxiv a license to display the preprint in perpetuity.

It is made available under a CC-BY-NC-ND 4.0 International license .

\section{Table 1: Demographic characteristics of respondents}

\begin{tabular}{|c|c|c|}
\hline Characteristics & $\begin{array}{l}\text { Total } \\
\mathbf{n}\end{array}$ & $\%$ \\
\hline Gender & 967 & \\
\hline Male & 869 & 89.9 \\
\hline Female & 98 & 10.1 \\
\hline Age & 961 & \\
\hline$<30$ & 111 & 11.6 \\
\hline $30-49$ & 786 & 81.8 \\
\hline$\geq 50$ & 64 & 6.6 \\
\hline Education & 966 & \\
\hline Primary school or less & 210 & 21.7 \\
\hline Secondary school & 462 & 47.8 \\
\hline High school or above & 294 & 30.4 \\
\hline Occupation & 967 & \\
\hline Full-time job & 718 & 74.3 \\
\hline Part-time job & 108 & 11.2 \\
\hline Unemployed & 141 & 14.5 \\
\hline Marital status & 966 & \\
\hline Single & 363 & 37.6 \\
\hline Married/live with partners & 448 & 46.4 \\
\hline Divorced/Separated/ Widowed & 155 & 16.0 \\
\hline Monthly income & 965 & \\
\hline$<4$ million VND & 330 & 34.2 \\
\hline 4 - 8 million VND & 432 & 44.8 \\
\hline$>8$ million VND & 203 & 21.0 \\
\hline Ever injected drugs & 967 & \\
\hline Yes & 754 & 78.0 \\
\hline No & 213 & 22.0 \\
\hline Injecting drug use within the past 3 months & 965 & \\
\hline Yes & 120 & 12.4 \\
\hline No & 845 & 87.6 \\
\hline Duration on MMT & 965 & \\
\hline$<1$ year & 128 & 13.3 \\
\hline $1-5$ years & 580 & 60.1 \\
\hline$>5$ years & 257 & 26.6 \\
\hline Daily Methadone dose (mg) & 967 & \\
\hline$<60 \mathrm{mg} /$ day & 245 & 25.3 \\
\hline $60-120 \mathrm{mg} /$ day & 398 & 41.2 \\
\hline$>120 \mathrm{mg} / \mathrm{day}$ & 324 & 33.5 \\
\hline
\end{tabular}


medRxiv preprint doi: https://doi.org/10.1101/2021.08.06.21261540; this version posted August 7, 2021. The copyright holder for this preprint (which was not certified by peer review) is the author/funder, who has granted medRxiv a license to display the preprint in perpetuity.

\section{It is made available under a CC-BY-NC-ND 4.0 International license.}

\begin{tabular}{lll}
\hline Characteristics & Total & n \\
\hline Dose missed in the last 3 months & 967 & \\
Yes & 433 & 44.8 \\
No & 534 & 55.2 \\
HIV positive & 967 & \\
Yes & 328 & 33.9 \\
No & 639 & 66.1 \\
ARV treatment & 312 & \\
Yes & 302 & 96.8 \\
No & 10 & 3.2 \\
Tuberculosis & 967 & \\
Yes & 10 & 1.0 \\
No & 957 & 99.0 \\
Hepatitis B & 967 & \\
Yes & 94 & 9.7 \\
No & 873 & 90.3 \\
Hepatitis C & 967 & \\
Yes & 405 & 41.9 \\
No & 562 & 58.1 \\
\hline
\end{tabular}

376 Notes: n, number of participants; MMT, methadone maintenance treatment; ARV, antiretroviral 377 treatment. 
medRxiv preprint doi: https://doi.org/10.1101/2021.08.06.21261540; this version posted August 7, 2021. The copyright holder for this preprint (which was not certified by peer review) is the author/funder, who has granted medRxiv a license to display the preprint in perpetuity.

It is made available under a CC-BY-NC-ND 4.0 International license .

Table 2: Profiles of EQ-5D-5L by age group

\begin{tabular}{|c|c|c|c|c|c|c|c|c|}
\hline \multirow{2}{*}{ Domains } & \multicolumn{2}{|c|}{$<\mathbf{3 0}$} & \multicolumn{2}{|c|}{$30-49$} & \multicolumn{2}{|c|}{$\geq \mathbf{5 0}$} & \multicolumn{2}{|c|}{ Total } \\
\hline & $\mathbf{n}$ & $\%$ & n & $\%$ & $\mathbf{n}$ & $\%$ & $\mathrm{n}$ & $\%$ \\
\hline Mobility & 111 & & 786 & & 64 & & 967 & \\
\hline No problems & 102 & 91.9 & 741 & 94.2 & 54 & 84.4 & 902 & 93.3 \\
\hline Slight problems & 6 & 5.4 & 29 & 3.7 & 3 & 4.7 & 38 & 3.9 \\
\hline Moderate problems & 2 & 1.8 & 8 & 1.0 & 3 & 4.7 & 14 & 1.5 \\
\hline Severe problems & 1 & 0.9 & 7 & 1.0 & 4 & 6.3 & 12 & 1.2 \\
\hline Unable to walk & 0 & 0.0 & 1 & 0.1 & 0 & 0.0 & 1 & 0.1 \\
\hline Self-care & 111 & & 786 & & 64 & & 967 & \\
\hline No problems & 108 & 97.3 & 767 & 97.5 & 60 & 93.8 & 940 & 97.2 \\
\hline Slight problems & 1 & 0.9 & 9 & 1.2 & 1 & 1.6 & 11 & 1.2 \\
\hline Moderate problems & 2 & 1.8 & 6 & 0.8 & 2 & 3.0 & 9 & 0.9 \\
\hline Severe problems & 0 & 0.0 & 3 & 0.4 & 1 & 1.6 & 6 & 0.6 \\
\hline Extreme problems & 0 & 0.0 & 1 & 0.1 & 0 & 0.0 & 1 & 0.1 \\
\hline Usual activities & 111 & & 786 & & 64 & & 967 & \\
\hline No problems & 100 & 90.1 & 734 & 93.3 & 58 & 90.6 & 897 & 92.8 \\
\hline Slight problems & 7 & 6.3 & 32 & 4.1 & 1 & 1.6 & 40 & 4.1 \\
\hline Moderate problems & 2 & 1.8 & 15 & 1.9 & 3 & 4.7 & 21 & 2.2 \\
\hline Severe problems & 2 & 1.8 & 3 & 0.4 & 2 & 3.1 & 7 & 0.7 \\
\hline Unable to do & 0 & 0.0 & 2 & 0.3 & 0 & 0.0 & 2 & 0.2 \\
\hline Pain/Discomfort & 111 & & 786 & & 64 & & 967 & \\
\hline No pain & 97 & 87.4 & 682 & 86.7 & 45 & 70.3 & 829 & 85.8 \\
\hline Slight pain & 10 & 9.0 & 70 & 8.9 & 8 & 12.5 & 88 & 9.1 \\
\hline Moderate pain & 2 & 1.8 & 28 & 3.6 & 8 & 12.5 & 39 & 4.0 \\
\hline Severe pain & 2 & 1.8 & 4 & 0.5 & 2 & 3.1 & 8 & 0.8 \\
\hline Extreme pain & 0 & 0 & 2 & 0.3 & 1 & 1.6 & 3 & 0.3 \\
\hline Anxiety/Depression & 111 & & 786 & & 64 & & 967 & \\
\hline Not anxious/depressed & 94 & 84.7 & 682 & 86.7 & 50 & 78.1 & 831 & 85.9 \\
\hline Slightly & 14 & 12.6 & 72 & 9.2 & 8 & 12.5 & 94 & 9.8 \\
\hline Moderately & 2 & 1.8 & 24 & 3.1 & 3 & 4.7 & 30 & 3.1 \\
\hline Severely & 1 & 0.9 & 5 & 0.6 & 2 & 3.1 & 8 & 0.8 \\
\hline Extremely & 0 & 0 & 3 & 0.4 & 1 & 1.6 & 4 & 0.4 \\
\hline
\end{tabular}


381 Table 3: EQ-5D-5L utility scores and EQ-VAS scores by different characteristics

\begin{tabular}{lllllll}
\hline & \multicolumn{2}{l}{ EQ-5D-5L scores } & \multicolumn{3}{c}{ EQ-VAS scores } \\
& Mean & SD & p-value & Mean & SD & p-value \\
\hline $\begin{array}{l}\text { Total } \\
\text { Gender }\end{array} \quad 0.96$ & 0.12 & & 75.8 & 15.5 & \\
$\quad$ Male & 0.96 & 0.11 & 0.249 & 75.8 & 15.2 & 0.949 \\
$\quad$ Female & 0.94 & 0.19 & & 75.7 & 17.7 & \\
Age & & & & & & \\
$\quad<30$ & 0.96 & 0.11 & $<0.001$ & 79.9 & 15.5 & $<0.001$ \\
$\quad 30-49$ & 0.96 & 0.11 & & 75.9 & 15.1 & \\
$\quad \geq 50$ & 0.9 & 0.2 & & 67.3 & 16.6 &
\end{tabular}

Education

Primary school or less

Secondary school

High school or above

Occupation

Full-time job

Part-time job

Unemployed

Marital status

Single

Married/live with partners

Divorced/Separated/

Widowed

Monthly income

$$
\begin{aligned}
& <4 \text { million VND } \\
& 4-8 \text { million VND } \\
& >8 \text { million VND }
\end{aligned}
$$

0.97

0.94

0.91

0.97

0.09

0.058

0.13

0.94

0.15

0.93

0.17

$<0.001$

0.08

0.97

0.08

0.97

0.96

0.96

0.12

0.62

0.12

Injecting drug use within the past 3 months

Yes

No

0.95

0.09

0.818

0.12

0.97

0.09

0.645

0.13

0.11

0.96

$<1$ year
$1-5$ years
$>5$ years

Daily Methadone dose (mg)

0.95

$<0.001$

uration on MMT

0.96

0.13
0.11

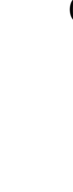

77.5

71.4

70.5

17.1

$<0.001$

76.2

15.7

77.6

13.4

76.2

15.1

0.791

75.6

15.3

75.3

16.9

72.2

17.6

$<0.001$

77.1

14.1

79

13.5

75

78.4

$15.6 \quad 0.005$

14.9

73.3

16.7

0.059

76.1

15.3 
medRxiv preprint doi: https://doi.org/10.1101/2021.08.06.21261540; this version posted August 7, 2021. The copyright holder for this preprint (which was not certified by peer review) is the author/funder, who has granted medRxiv a license to display the preprint in perpetuity.

It is made available under a CC-BY-NC-ND 4.0 International license.

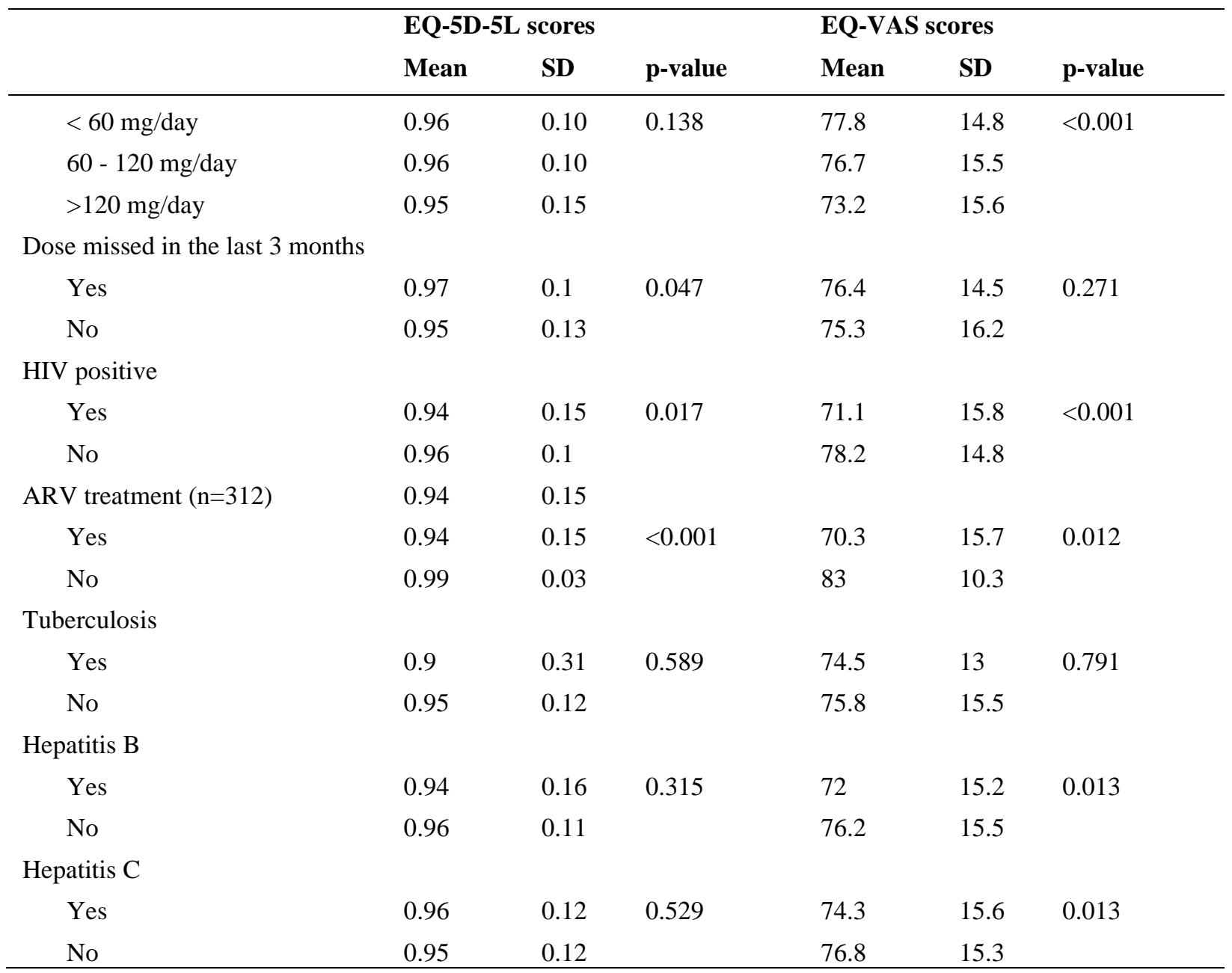


medRxiv preprint doi: https://doi.org/10.1101/2021.08.06.21261540; this version posted August 7, 2021. The copyright holder for this preprint (which was not certified by peer review) is the author/funder, who has granted medRxiv a license to display the preprint in perpetuity.

It is made available under a CC-BY-NC-ND 4.0 International license .

384 Table 4: EQ-5D-5L utility scores and EQ-VAS scores by different substance uses

\begin{tabular}{lcccccc}
\hline & \multicolumn{2}{c}{ EQ-5D-5L scores } & \multicolumn{5}{c}{ EQ-VAS scores } \\
& Mean & SD & p-value & Mean & SD & p-value \\
\hline Hazardous tobacco use (ASSIST $\geq 4)$ & & & & & & \\
$\quad$ Yes (n=941) & 0.96 & 0.11 & 0.418 & 75.8 & 15.5 & 0.954 \\
$\quad$ No (n=26) & 0.91 & 0.31 & & 76.0 & 14.3 & \\
Hazardous alcohol use (ASSIST $\geq 11$ ) & & & & & & \\
$\quad$ Yes (n=81) & 0.95 & 0.09 & 0.707 & 76.0 & 15.2 & 0.888 \\
$\quad$ No (n=886) & 0.96 & 0.12 & & 75.8 & 15.5 & \\
Hazardous ATS use (ASSIST $\geq 4)$ & & & & & & \\
$\quad$ Yes (n=161) & 0.95 & 0.13 & 0.251 & 71.7 & 17.0 & $<\mathbf{0 . 0 0 1}$ \\
$\quad$ No (n=806) & 0.96 & 0.12 & & 76.6 & 15.1 & \\
Positive urine test with ATS & & & & & & \\
$\quad$ Yes (n=246) & 0.96 & 0.11 & 0.491 & 76.4 & 14.7 & 0.490 \\
$\quad$ No (n=721) & 0.96 & 0.12 & & 75.6 & 15.8 & \\
Hazardous opioids use (ASSIST $\geq 4)$ & & & & & & \\
$\quad$ Yes (n=825) & 0.96 & 0.12 & 0.171 & 75.7 & 15.5 & 0.564 \\
$\quad$ No (n=142) & 0.94 & 0.14 & & 76.5 & 15.5 & \\
Hazardous cannabis use (ASSIST $\geq 4)$ & & & & & & \\
$\quad$ Yes (n=25) & 0.91 & 0.16 & 0.112 & 69.6 & 13.7 & $\mathbf{0 . 0 4 3}$ \\
$\quad$ No (n=942) & 0.96 & 0.12 & & 76.0 & 15.5 & \\
\hline
\end{tabular}

386 Notes: ASSIST, The Alcohol, Smoking and Substance Involvement Screening Test 
medRxiv preprint doi: https://doi.org/10.1101/2021.08.06.21261540; this version posted August 7, 2021. The copyright holder for this preprint (which was not certified by peer review) is the author/funder, who has granted medRxiv a license to display the preprint in perpetuity.

It is made available under a CC-BY-NC-ND 4.0 International license .

387 Table 5: Most frequent EQ-5D-5 L health states with mean utility scores and EQVAS

388 scores

\begin{tabular}{llllll}
\hline Health states & Number & Percent & Cum\% & Mean Utility & Mean VAS \\
\hline 11111 & 752 & 77.8 & 77.8 & 1.00 & 78.5 \\
11112 & 37 & 3.8 & 81.6 & 0.94 & 74.6 \\
11121 & 28 & 2.9 & 84.5 & 0.92 & 65.5 \\
11122 & 20 & 2.1 & 86.6 & 0.85 & 72.4 \\
11131 & 16 & 1.7 & 88.3 & 0.85 & 55.6 \\
11211 & 7 & 0.7 & 89.0 & 0.95 & 71.4 \\
11113 & 7 & 0.7 & 89.7 & 0.89 & 76.4 \\
21111 & 6 & 0.6 & 90.3 & 0.93 & 80.0 \\
11222 & 5 & 0.5 & 90.8 & 0.81 & 70.0 \\
11221 & 5 & 0.5 & 91.3 & 0.87 & 67.0 \\
\hline
\end{tabular}

389

390 
medRxiv preprint doi: https://doi.org/10.1101/2021.08.06.21261540; this version posted August 7, 2021. The copyright holder for this preprint (which was not certified by peer review) is the author/funder, who has granted medRxiv a license to display the preprint in perpetuity.

It is made available under a CC-BY-NC-ND 4.0 International license .

Table 6: Multivariate linear regression model of factors related to EQ-5D-5L and EQ-VAS scores

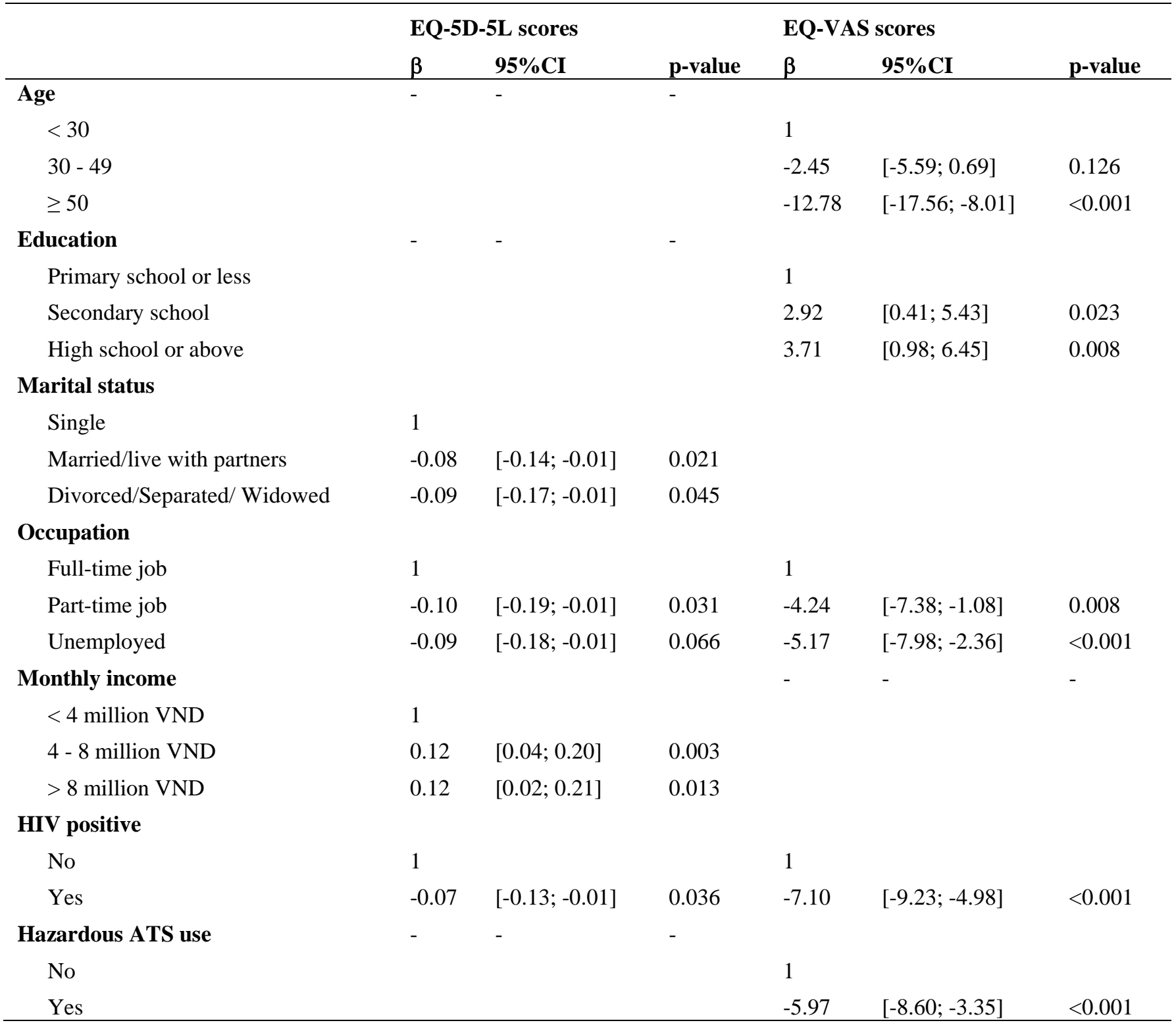

394 Notes: CI, confidence interval 